\title{
LA ESTRELLA COMO ELEMENTO PERTURBADOR: GRETA GARBO Y SU RECEPCIÓN EN LA ESPAÑA DE LOS AÑOS VEINTE Y TREINTA
}

\author{
The Star as A Disruptive Force: \\ Greta Garbo and Its Reception in Spain in the Twenties and Thirties \\ Evelyne Coutel ${ }^{\mathrm{a}}$ \\ Escuela Normal Superior de Lyon, Francia \\ DOI: http://dx.doi.org/10.15366/secuencias2017.46.002
}

\begin{abstract}
RESUMEN
Este trabajo estudia de qué manera se construyó la imagen de Greta Garbo en el contexto específico de la España de los años veinte y treinta, periodo en el cual la prensa cinematográfica conoce un gran impulso con la aparición de revistas como Popular Film o La Pantalla. La recepción de Garbo se pone en relación con los debates en torno a la cinematografía nacional, marcados por un rechazo de la españolada y de los estereotipos femeninos hollywoodienses que convocaban el espectro de Carmen y que Garbo trató de superar por su negación a interpretar papeles de vampiresa. Se observa así que, a finales de los años veinte, su figura fue acogida de forma muy positiva y algunos intelectuales la consagraron como «estrella-autora». Se analizan luego los cambios surgidos a partir de los años treinta, cuando la proclamación de la Segunda República supuso una mejora de la condición femenina, despertando una crisis de masculinidad que se plasmó en la cultura cinematográfica y que llevó a unos críticos a reivindicar la superioridad del «director», presentado como auténtico guardián del genio creador a expensas de la estrella, en adelante combatida y denigrada con el fin de reafirmar el estatuto de la creación artística como propiedad masculina. Se estudia, en último lugar, la influencia de Greta Garbo en el público femenino español, lo cual permite entender mejor lo antes descrito.
\end{abstract}

Palabras clave: Greta Garbo, star system, estudios de género, estudios de recepción, autoría, España, siglo xx.

\begin{abstract}
This article studies how Greta Garbo's star image was built in the specific context of Spain in the twenties and thirties, a period in which film journals enjoyed a boost in this country thanks to the arrival of magazines such as Popular Film or La pantalla. Garbo's reception is connected with the debates on national cinema, characterized by the rejection of the «españolada» and Hollywood female stereotypes such as vamps that brought the spectre of Carmen back, stereotypes Garbo had tried to overcome through her rejection of playing such roles. In the late twenties, her image was positively regarded and some intellectuals described her as a «star-author». Then I analyse the changes occurred in the thirties, when the proclamation of the Second Republic meant an improvement of women's status that triggered a crisis of masculinity. Such crisis can be traced in cinematographic culture as some journalists claimed the director's «superiority», now presented as the authentic custodian of creative genius to the detriment of stars, which were henceforth attacked and denigrated with the aim of reasserting the status of the artistic creation as a male prerogative. Finally, this paper focuses on the influence of Greta Garbo on Spanish female spectatorship, which helps to better understand what has been previously described.
\end{abstract}

Keywords: Spain, twentieth century, star system, Greta Garbo, gender studies, film creation, film author.

[a] Evelyne Coutel es doctora por la Universidad Paris IV-París Sorbona y profesora titular de la ENS de Lyon, donde imparte docencia en el Departamento de Lenguas, Literaturas y Civilizaciones Extranjeras. Es miembro del IHRIM (Instituto de Historia de las Representaciones y de las Ideas en las Modernidades, UMR 5317) y miembro asociado del CRIMIC (Centro de Investigaciones Interdisciplinarias sobre los Mundos Hispánicos Contemporáneos, EA 2561). En su tesis doctoral ha estudiado la recepción de Greta Garbo en la cultura cinematográfica española de la primera mitad del siglo xx, basándose principalmente en las revistas especializadas de aquel periodo. Sus temas de investigación se ubican dentro de la historia cultural del cine. Incluyen sobre todo el estudio de los modelos femeninos difundidos a través de la cultura cinematográfica y abarcan también problemáticas como el concepto de autor cinematográfico o las relaciones entre el cine y las demás artes. E-mail: evelyne.coutel@ens-lyon.fr 
En 1934, el periodista Aurelio Pego inventó el neologismo «garbitis» para nombrar un fenómeno que consistía, según él, en «una inflamación de la visión de la excelsa artista sueca» ${ }^{1}$. Aludía por supuesto a Greta Garbo. Este neologismo - al igual que otros como «gretagarbismo», "gretismo», "garbismo», "gretagarboniano»- demuestra de por sí la omnipresencia de esta estrella en la cultura cinematográfica de los años veinte y treinta ${ }^{2}$, así como la ambivalencia que pudo despertar entre los críticos y los públicos. De hecho, en el citado artículo, afirmaba Pego lo siguiente: «en eso está el secreto indeleble de la Garbo, que se la ve, procura una tortura tal a la imaginación, que ya nos es difícil olvidarla. A otras artistas se las mira, a la Garbo se nos graba ${ }^{3}$ ». El léxico empleado por el periodista («tortura»), que parece preso de su admiración, evidencia el carácter problemático de esta estrella que pudo ser objeto tanto de fascinación como de repulsión o generar una mezcla de ambos sentimientos.

El examen de las revistas cinematográficas españolas que se publicaron en un periodo correspondiente al nacimiento y a la consolidación de su imagen —o sea, entre 1926 y 1935 aproximadamente - indica que el debate en torno a los modelos femeninos cristalizó en la figura de Greta Garbo, quizás mucho más en España que en otros países europeos como Francia o Alemania. En este trabajo se destacarán factores y circunstancias específicas que apoyen esta hipótesis y se mostrará hasta qué punto la imagen de Garbo supuso todo un fenómeno sociocultural en la medida en que alimentó la reflexión en torno a varias problemáticas esenciales que estaban movilizando a los críticos, en particular la necesidad de combatir los estereotipos folclóricos, recuperados sobre todo por Hollywood, y la voluntad de reivindicar la calidad artística del cine, en un contexto marcado por los avances del primer feminismo español, que diluían las fronteras entre lo masculino y lo femenino e implicaban a la vez una revalorización del estatuto de las mujeres en el seno de la cultura y de la creación artística. Se analizarán los discursos ambivalentes, admirativos o vindicativos que dinamizaron la prensa cinematográfica y la convirtieron más que nunca en plataforma de construcción del género. Para ello, se estudiará primero de qué manera se configuró el mito de Greta Garbo en la cultura cinematográfica española de la segunda mitad de los años veinte y cuáles fueron los factores que engendraron entonces un discurso mayoritariamente positivo que la consagró como «estrella-autora». Se examinará luego la hostilidad que suscitó la actriz a partir de 1930, un hecho que se pondrá en relación con la ambigüedad sexual de las estrellas y con la influencia que tuvo Garbo en el público femenino.

\section{El nacimiento de una nueva imagen femenina (1926-1930)}

En la segunda parte de los años veinte, los discursos que circularon en la prensa de cine española acerca de Greta Garbo fueron, en su inmensa mayoría, eminentemente positivos y la presentaron como la «mujer ideal», construyendo una imagen fuertemente apetecible tanto para el público femenino como para
[1] Aurelio Pego, «Catalina, eje», (Popular Film n. ${ }^{\circ}$ 399, 5 de abril de 1934).

[2] Nos importa subrayar que el proyecto de estudiar el impacto de Greta Garbo en la cultura cinematográfica española no surgió de una predilección personal por esta actriz, sino que llegó a imponerse tras la consulta de las revistas cinematográficas publicadas entre 1926 y 1937. La comprobación de la centralidad de esta estrella en la prensa de cine española originó este trabajo y planteó la necesidad de analizar su recepción.

[3] Aurelio Pego, "Catalina, eje».

[4] La filmografía de Greta Garbo en Hollywood consta de veinticinco películas rodadas entre 1926 y 1941. Antes de que Louis B. Mayer la reclutara durante un viaje que hizo a Europa, Garbo había actuado en dos largometrajes: La leyenda de Gösta Berling (Gösta Berlings saga, Mauritz Stiller, 1924) y Bajo la máscara del placer (Die Freudlose Gasse, G.W, Pabst). 
[5] Mireille Dottin-Orsini, Cette femme qu'ils disent fatale. Textes et images de la misogynie fin de siècle (Paris, Bernard Grasset, 1993), pp. 274-305. Véase también Bram Dijkstra, Ídolos de perversidad: la imagen de la mujer en la cultura de fin de siglo (Madrid, Debate / Barcelona, Círculo de lectores, 1994).

[6] En su acepción más general, la mujer fatal se define como la proyección o materialización de las fantasías y de los miedos masculinos. Se caracteriza por su profunda ambigüedad, tanto por los sentimientos que inspira -entre repulsión y deseo- como por la interpretación que se puede dar de ella: por un lado, es reflejo de la misoginia que le dio forma, pero, al mismo tiempo, expresa y materializa la noción de dominación femenina.

[7] Edgar Morin, Las stars. Servidumbres y mitos (Barcelona, Dopesa, 1972), p. 35.

[8] Rafael Martínez Gandía, «Nita Naldi, vampiresa de ayer», (Mundo Gráfico, n. ${ }^{\circ}$ 992, 5 de noviembre de 1930). el masculino. Conviene identificar, pues, los parámetros que influyeron en esta primera recepción favorable.

La actriz empezó su carrera hollywoodiense en el año 1925, en el mismo momento en que la prensa cinematográfica española estaba en pleno auge, en particular gracias a la aparición de revistas como Popular Fỉm (1926-1937) y La Pantalla (1927-1929). Para entender el impacto que iba a provocar esta estrella es indispensable recordar la existencia de un arquetipo femenino que por entonces daba mucho que hablar en la prensa cinematográfica debido al relieve que le dio el cine, cuyos personajes echan raíces en la literatura y las artes pictóricas: se trata de la mujer fatal, también llamada «vampiresa», aunque esta última constituye más bien una modalidad de la mujer fatal que fue declinada como vampiro en las artes europeas a lo largo del siglo $\mathrm{xIX}^{5}$. Sin embargo, a nivel terminológico, ambas denominaciones - «mujer fatal» $\mathrm{y}$ «vampiresa»- suelen ir juntas en la prensa cinematográfica y se confunden hasta llegar a ser perfectamente sinónimas ${ }^{6}$.

$\mathrm{Si}$ en la literatura y las artes pictóricas la mujer fatal era un ente completamente dependiente de su creador y podía verse como la plasmación de la misoginia decimonónica, el cine introduce una novedad, ya que el estereotipo de la vampiresa viene encarnado ahora por una actriz de carne y hueso que le puede dar un toque personal y convertirlo en un modelo interesante para la mujer espectadora, tanto más cuanto que en el cine, la recepción de los modelos femeninos puede verse influenciada por la difusión de la vida privada de las actrices que los interpretan. Como lo ha subrayado Edgar Morin7, este es el mecanismo básico e imprescindible para que nazca una estrella. La interrelación entre persona y personaje se comprobará a lo largo de este trabajo a través del caso de Greta Garbo.

Durante los años diez y veinte, e incluso más allá de este periodo, el dispositivo narrativo y visual de las cintas hollywoodienses se estructuró en torno a dos modelos femeninos opuestos: la ingenua y la vampiresa. Mientras esta desencadenaba las peripecias destruyendo hogares, aquella brindaba un contraejemplo virtuoso. Dentro de este sistema androcéntrico que representa la feminidad de acuerdo con los intereses masculinos, lo normal era que la vampiresa fuese encarnada por una actriz procedente de Oriente, del sur de Europa o de Latinoamérica (o cuyo físico evocaba tales orígenes), mientras las ingenuas solían ser protagonizadas por actrices norteamericanas. En un artículo dedicado a la actriz Nita Naldi, el crítico Rafael Martínez Gandía se hizo eco de este mecanismo que, por lo visto, disgustó a quienes eran oriundos de estos territorios y empezaron a ver con malos ojos que la mujer europea -en particular la española y la italiana - fuera pintada de tal manera:

Nita Naldi nació en Italia. Estaba, por tanto, destinada irremediablemente a encarnar papeles de seductora, porque hasta hace poco no se comprendía que una mujer latina pudiera ser en los films otra cosa que la perdición de los hombres. Puede ser que hubiera alcanzado más fortuna en interpretaciones distintas; pero su sino era ser siempre la coqueta perversa e impía, y en las películas no debía tener otra ocupación que destrozar corazones masculinos con sus ojos de almendra... ${ }^{8}$ 
De hecho, la demonización de la mujer sureña que se llevaba a cabo en las películas a través del binomio ingenua/vampiresa no hizo sino reactivar un debate surgido en el siglo xix y que, en el primer tercio del siglo xx y posteriormente, siguió acalorando los ánimos. Esta controversia sacaba su origen en Carmen, la famosa novela de Mérimée, publicada en 1847. Como se sabe, el auge de los nacionalismos durante el siglo xix trajo consigo la idea de que el valor y la grandeza de una nación estriban en el comportamiento de sus mujeres y en su grado de virtud 9 . De ahí que la figura de Carmen, una modalidad de la mujer fatal que sería utilizada por Hollywood para crear personajes de vampiresa, causara tanto disgusto en España, donde era inconcebible que una mujer tan deshonrosa fuese considerada como representativa de la mujer española.

De forma general, las vampiresas hollywoodienses interpretadas por actrices como Theda Bara - pionera en la materia desde Érase una vez un loco (A Fool There Was, William Fox, 1915) - pudieron resultar antipáticas e inquietantes sencillamente por cuestionar el modelo de la ingenua y, a partir de los años veinte, por su dimensión exageradamente teatral que no cuadraba con el realismo al que el cine debía aspirar. Sin embargo, en el caso específico de un país como España, hubo otros factores de desacuerdo y la relación que los públicos pudieron mantener con este estereotipo resultó más compleja.

Cuando Greta Garbo llegó a Hollywood, la Metro-Goldwyn-Mayer (MGM) no supo muy bien qué hacer con ella. De origen sueco, no venía del sur sino del norte de Europa y quedaba claro que no cabía en ninguna de las dos categorías ingenua/vamp. Las dudas que tuvieron sus productores a la hora de darle su primer papel se patentizan claramente en su primera película, El torrente (Torrent, Monta Bell, 1926), una adaptación de la novela de Blasco Ibáñez Entre naranjos (1900). En palabras de Terenci Moix, la interpretación de Greta Garbo en esta cinta constituye «uno de los más asombrosos casos de transformismo de la historia del cine ${ }^{10}$. En efecto, al inicio de El torrente, la actriz encarna a una buena campesina dispuesta a casarse con Rafael Brull y que, a raíz de la negativa de la madre de este, acaba convertida en una vampiresa de reminiscencias «carmenescas», con múltiples vaivenes entre ambos estereotipos a lo largo de la cinta. En la última secuencia de la cinta, se la ve en un teatro madrileño interpretando a Carmen, lo cual resulta arbitrario dado que esta no se menciona en la novela original. Aunque el personaje de Leonora Moreno dibujado por Blasco Ibáñez se caracterice por su voluptuosidad y esté presentado como una «amazona viril» ${ }^{11}$ capaz de someter a los hombres, no se trata propiamente de una mujer fatal, «ingrediente» que, por lo visto, no puede faltar en una película que se nutre del folklore hispánico.

Este ejemplo indica que Hollywood no podía dejar de encasillar a sus actrices en uno $\mathrm{u}$ otro polo del binomio ingenua/vamp. Solo ellas estaban capacitadas para sublimar los estereotipos cinematográficos con su talento y su personalidad, aunque muchas veces este proceso se viera dificultado por lo codificado de los papeles que se les encomendaba. La segunda película de Garbo, La tierra de todos (The Temptress, Mauritz Stiller/Fred Niblo, 1926),
[9] Véase, por ejemplo, Xavier Andreu Miralles, «La mirada de Carmen. El mite oriental d'Espanya i la identitat nacional», (Afers: fulls de recerca $i$ pensament, vol.19, n. ${ }^{\circ} 48$, 2004), pp. 347-367; Geoff Eley, "Culture, Nation and Gender», en Ida Blom, Karen Hagemann, Catherine Hall (dirs.), Gendered Nations. Nationalisms and Gender Order in the Long Nineteenth-Century (Oxford/ New-York, Berg, 2000), pp. 27-40.

[10] Terenci Moix, La Gran Historia del Cine (ABC, 1996), p. 683 .

[11] Vicente Blasco Ibáñez, Entre naranjos (Madrid, Cátedra, 2009), p. 262. 
otra adaptación de una novela de Blasco Ibáñez ${ }^{12}$, ofrece buen ejemplo de ello. El mismo título evidencia su asimilación a la vampiresa y la consagra como otra especialista más de semejantes papeles. A juzgar también por su título, la película siguiente, El demonio y la carne (Flesh and the Devil, Clarence Brown, 1926), debía confirmar la tendencia. Sin embargo, la interpretación de Felicitas von Rhaden introdujo una fuerte ambigüedad en torno a quién era Garbo y a qué tipo de mujer correspondía. El resultante desconcierto, así como la falta de una etiqueta adecuada a la hora de valorar su papel, aparece muy bien en el artículo que el periodista Apolo M. Ferri publicó en El cine a raíz del estreno de dicha película. El periodista afirma primero: "para el rol de Greta en El demonio y la carne, parece indicado el nombre de "mujer fatal”, eso que también suele llamarse en el argot cinemático americano "vamp" o vampiresa». Sin embargo, en las líneas siguientes, no dejará de poner de manifiesto las diferencias que existen entre las vampiresas anteriores y la nueva imagen femenina que se perfila en Garbo:

Greta Garbo es la actriz que da mayor impresión de intelectualidad en su trabajo. Se admira que todos sus gestos, que su menor movimiento, obedecen a un resorte cerebralmente administrado. Por eso, las emociones que nos transmite son unas emociones elevadas, no un simple impulso de animalidad más o menos elevada.

Ante ninguna mujer hemos sentido una sexualidad más refinada. Greta dignifica su femenino en atavismos que obran subconscientemente sobre el personaje que encarna, pero se adivina que esta elevada sensación de feminismo ha sido lograda conscientemente, por los nobles caminos de un estudio psicológico ${ }^{13}$.

[12] Nótese que en español se conservó el título de la novela original.

[13] Apolo M. Ferri, «Greta Garbo» (El Cine, n. ${ }^{\circ} 801,18$ de agosto de 1927).

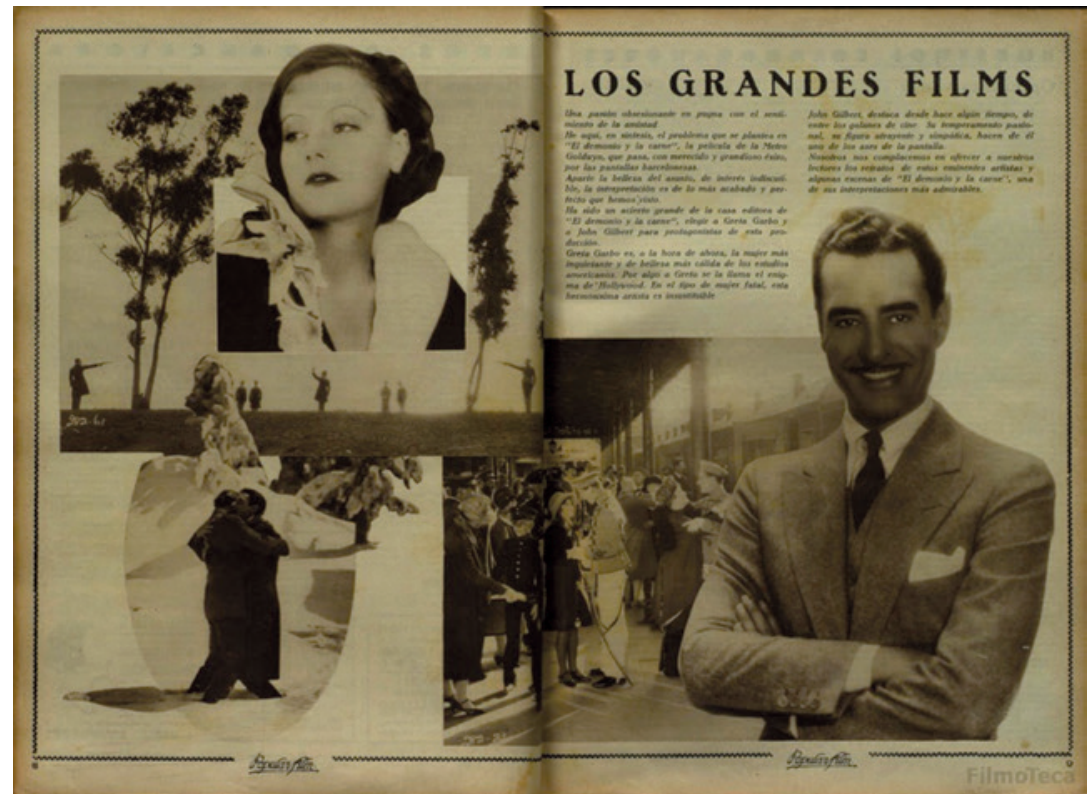

«Los grandes films» [Imágenes promocionales de El demonio y la carne] (Popular Film, n. ${ }^{\circ}$ 77, 19 de enero de 1928) 
En la mayoría de las biografías de Garbo, se ha dicho que la MGM la había reclutado por despecho: la productora quería contratar a su mentor Mauritz Stiller y, a sabiendas de que este nunca se hubiera marchado sin su protegida, le ofreció también un contrato. En realidad, lo contrario es más probable: Mayer había visto La leyenda de Gösta Berling (Gösta Berlings saga, Mauritz Stiller, 1924) en Hollywood y le interesaba mucho más Garbo que Stiller, aunque en aquel momento no dejara traslucir sus intenciones ${ }^{14}$. Como lo explica la actriz Louise Brooks en su autobiografía, Hollywood estaba en busca de una nueva imagen femenina que fuera capaz de expresar un deseo de emancipación sexual sin levantar susceptibilidades, tanto respecto de los públicos como de la censura. La sustitución de la censura por el Código Hays (que se hizo efectiva en veinticuatro estados en 1925) impuso una evolución de los tipos y, si unos actores como Adolfo Menjou o John Gilbert habían logrado ser aceptados interpretando personajes de moralidad dudosa, los productores se dieron cuenta de que no tenían al equivalente femenino que pudiera hacer lo mismo ${ }^{15}$.

La impresión de diferencia que producen las vampiresas interpretadas por Garbo se debe, pues, a una conjunción de factores entre los cuales destacan las características personales de la actriz, sus ambiciones respecto de los papeles que se le encomendaran y los propósitos de la MGM. Sin embargo, es de notar que en la prensa cinematográfica - extranjera como española- esta diferencia se atribuyó exclusivamente a la voluntad, y muchas veces a los méritos, de Garbo. Esta impresión o, mejor dicho, creencia, se afianzaría con la difusión de datos extra-fílmicos, en particular los del enfrentamiento entre la actriz y sus productores que se inició después del rodaje de El demonio y la carne. Insatisfecha con sus papeles de vampiresa, que le parecían tan ridículos como falsos ${ }^{16}$, Garbo exigió que le dieran roles más auténticos y le subieran el sueldo. Tras un dilatado periodo de negociaciones, la MGM no tuvo más remedio que aceptar, lo que provocó turbulencias en la prensa norteamericana y extranjera. Mientras los requisitos de la estrella indignaron a quienes los interpretaron como el resultado de un comportamiento ingrato y caprichoso, también entusiasmaron a otros, reforzando la admiración que Garbo podía inspirar. En julio de 1929, la revista Atlántico publicó un poema de Antonio de Obregón que se hizo eco, metafóricamente, de esos eventos que alimentaban el mito: «El león de la Metro Goldwyn / lame los pies de Greta Garbo» ${ }^{17}$.

De forma nítida, Garbo quedó como un emblema de mujer reivindicativa, de carácter fuerte y que, lejos de interpretar pasivamente sus papeles, dictaba sus propias condiciones. Hasta cierto punto, la actitud «caprichosa» de Garbo se puso en relación con los papeles que interpretaba en la pantalla y pudo reforzar su leyenda de mujer fatal. Pero, por otra parte, la actriz se granjeó la simpatía de quienes estaban cansados de ver a las actrices europeas encasilladas en semejantes papeles y que entendieron que la aparición de Greta Garbo suponía el nacimiento de una imagen femenina totalmente inédita, en ruptura con la vampiresa clásica. En la Historia del
[14] Barry Paris, Garbo (Minneapolis, University of Minnesota Press, 2005), p. 150.

[15] Según Brooks, «no tenían a otra heroína que fuera joven, bella y que tuviera suficiente personalidad para lograr que el amor libre tuviera buena acogida. [...] La apasionada Pola Negri [...] había muerto en las taquillas. Y los productores sacaban de quicio a las actrices -envolviendo a Barbara La Marr en un velo de monja para que resultara simpática y pegando una rosa entre los dientes de la virgen más famosa de la pantalla de Hollywood, Lois Wilson, para que pareciera sexi». Louise Brooks, Lulu in Hollywood (New York, Knopf, 1982), pp. 87-88. (La traducción es nuestra).

[16] En diciembre de 1926, la revista Motion Picture Magazine daba a conocer esta opinión al transcribir las palabras de Garbo: «Fíjese usted, iyo no quería ser una mala mujer en la pantalla! iEste es mi único problema en América. iLa gente dice que soy lo que ustedes llaman "el tipo de la vamp"! Sé lo que quieren decir, pero no creo que esto me corresponda. iNo me gusta hacer de "mala mujer"! Antes al contrario, prefiriría interpretar a buenas mujeres - buenas pero interesantes- ¿entiende usted?». Doris Markham, «An Idyl or a Tragedy - Which?» (Motion Picture Magazine, diciembre 1926) (La traducción es nuestra).

[17] Antonio de Obregón, «Programa» (Atlántico, 5 de julio de 1929). Reproducido en José María Conget, Viento de cine: el cine en la poesía de expresión castellana. 1900-1999 (Madrid, Hiperión, 2002), p. 21. 
[18] Ángel Zúñiga, Una historia del cine (Barcelona, Destino, vol. 2, 1948), p. 123.

[19] Íbid. (vol. 1), p. 115.

[2o] Ángel Zúñiga, La maravillosa mentira de Greta Garbo (Barcelona, G.P., h. 1953), p. 62.

[21] Sobre las protestas ocasionadas por la españolada entendida como tal en la prensa cinematográfica de los años veinte y treinta, en un contexto de promoción de un cine nacional que fuera el emblema de la «españolidad», véase Marta García Carrión, Por un cine patrio. Cultura cinematográfica y nacionalismo español (19261936) (Valencia, Publicacions de la Universitat de València, 2013), pp. 165-209.

[22] Antonio Heras, "Informaciones del cine: la figura de Greta Garbo", (Mundo Gráfico, n. ${ }^{\circ}$ 960, 26 de marzo de 1930).

[23] Anette Tapert, The Power of Glamour (New York, Crown Publishers, 1998), pp. 205-223. cine que publicó en 1948, el crítico español Angel Zuñiga, quien asistió al nacimiento del mito de Garbo, resume muy bien la lectura que se pudo hacer de él en España. Protesta Zúñiga contra «esa trasnochada etiqueta de vamp que en el estudio americano quisieron colgarle a su carrera como imposible sambenito ${ }^{18}$. Este crítico, según el cual la Carmen interpretada años antes por Theda Bara había supuesto "otro toque a la españolada» ${ }^{19}$, no podía sino tomar partido por la actriz sueca: «cuando nadie la comprendía, estuvimos con ella porque vimos la perspectiva nueva que traía a la pantalla, pese a la inútil etiqueta de "mujer fatal" con que nos la sirvió el Estudio. Porque se quería que la "europea" representase el mal, donde la ingenua americana era la encarnación del bien ${ }^{20}$.

En España, la percepción de la mujer fatal como problema y como ingrediente de la consabida españolada - en su acepción de género fílmico que difunde una visión caricaturesca de España como país atrasado y reducible a unos estereotipos ${ }^{21}$ - favoreció una admiración que a finales de los años veinte parece casi unánime, según se puede ver en las revistas cinematográficas. El culto que se desarrolló entonces en torno a Garbo se debió, además, a su capacidad para apoderarse de la pantalla, hundiendo a los públicos en un éxtasis y un asombro que ninguna actriz parecía haber provocado hasta el momento. Sirva de ejemplo este testimonio del periodista Antonio Heras, publicado en 1930:

\begin{abstract}
Al terminar de ver una película en que actúe Greta Garbo - no hace falta dejar transcurrir el tiempo para que ello ocurra- nos cuesta trabajo ya recordar los detalles del asunto, las imágenes de los demás actores... La figura de Greta Garbo todo lo invade, lo domina, empequeñeciendo y anulando cuanto no es ella ni su arte. ¿En qué consiste esta fuerza, este misterioso poder? [...] $\mathrm{Al}$ actuar Greta Garbo -en los gestos de su rostro, en los movimientos, aun menos perceptibles, de toda su persona-, nos parece sentir la vibración de la vida entera; se nos figura estar asomados al abismo, profundo, sin límites, desoladoramente trágico a las veces, de un gran espíritu... ¿En qué consistirá - vuelvo a preguntarme- el misterio fascinador y dominador de la figura de Greta Garbo, que vista una vez, ya no puede ser olvidada?22
\end{abstract}

Como ocurre con las demás estrellas, el poder carismático que Garbo ejerció desde sus primeras películas radicaba a la vez en sus ventajas personales y en intervenciones externas. Por un lado, su rostro tenía proporciones exactas: el espacio entre sus ojos equivalía a la anchura de un ojo y su nariz medía la tercera parte de la distancia que hay entre el pelo y la barbilla. El grosor de su labio inferior apenas superaba el del superior y eran tan largas sus pestañas que parecían postizas ${ }^{23}$. Por otro lado, desde sus comienzos en Europa, la actriz tuvo que sufrir algunas transformaciones físicas. Cuando la reclutó para el papel femenino de Gösta Berling, su mentor Mauritz Stiller le pidió que adelgazara diez kilos y le impuso una dieta estricta. A su vez, Hollywood hizo cuanto estaba en su mano para que Garbo se convirtiera en una estrella glamurosa, alineando sus dientes y «feminizando» su guardarropa. El papel del diseñador Adrian fue también decisivo en este proceso de construcción de 
la imagen de Garbo como mujer moderna, dotada de un estilo personal y único que hará que el público femenino se fije en ella, maravillándose ante lo original y lo «modernista» de sus trajes, cuando la actriz no demostraba especial interés por la indumentaria ${ }^{24}$.

En las citadas líneas, el periodista no parece consciente de que, en la economía del star system, todo está hecho para poner a la estrella en el primer plano, tanto más cuanto que las cintas de Hollywood funcionan a menudo como vehicles, es decir, que su principal objetivo consiste en promover a una estrella o en fortalecer su leyenda si ya goza de gran popularidad. En su artículo, todos los procedimientos que contribuyen a producir esta impresión de centralidad pasan totalmente desapercibidos y todo el mérito se lo lleva la actriz. Además de ejemplificar la fascinación sin límite que despierta Garbo, los comentarios de Heras permiten introducir otro elemento de gran relevancia: la noción de «estrella-autora», que supera incluso el estatuto de star as performer ${ }^{25}$ que también le corresponde.

El concepto de «estrella-autora» resulta fundamental para entender el cambio de orientación que surgirá en los años treinta. Para ilustrarlo, basta con citar a César Arconada, quien escribió en 1929 la primera biografía de la actriz titulada Vida de Greta Garbo, en la cual afirma lo siguiente:

En sus obras manda ella mucho más que su director. Greta es una artista individual. Donde ella se mueva estará el eje de la obra. Su nivel es alto: y domina. Crea un sistema de gravitación y somete a él todos los personajes de la obra. Es un temperamento dominante, absorbente. Todos los personajes de la obra viven, no solo condicionados a ella, sino influenciados, sujetos a su mandato psicológico ${ }^{26}$.

La manera en la que Greta Garbo llevaba a cabo tanto su vida profesional -imponiendo sus propias condiciones- como su vida personal - se negaba a contraer matrimonio-, formó parte de la construcción de su imagen que por su carácter inédito resultaba misteriosa. Este misterio, fortalecido por la costumbre de la actriz de rechazar las entrevistas periodísticas y por su malestar frente a la popularidad que la llevaba a esconderse, se combinó con sus papeles y dio lugar a una figura indescifrable. De hecho, no se sabía si esta actitud era espontánea o si era parte de una estrategia definida por la misma actriz que así pretendía alimentar el mito. Lo que sí es cierto es que Hollywood supo aprovechar la «frialdad» de la actriz para desarrollar una publicidad mitificante, presentándola como «la esfinge sueca», una imagen que se entroncaba con la orientalización de las actrices catalogadas como mujeres fatales - siendo Theda Bara la primera en haber sido objeto y víctima de este procedimiento-, pero que, a la vez, añadía un exotismo norteño capaz de despertar la curiosidad de los públicos sureños.

$\mathrm{Al}$ mismo tiempo, Garbo fue la máxima encarnación de la independencia femenina y, en los últimos años de la dictadura primorriverista, cuando el primer feminismo español iba ganando cada vez más terreno, esta imagen ejerció una influencia notable en el público femenino, como lo recordaría años después Santiago Aguilar en Cinegramas: «El demonio y la carne conmovió todos los
[24] Véase Lucy Fischer, Designing Women: Cinema, Art Deco and the Female Form (New York, Columbia University Press, 2003), pp. 109-121.

[25] En su artículo «Re-examining Stardom», Christine Geraghty destaca tres categorías de estrellas: la «star as celebrity", cuya popularidad se basa ante todo en la difusión de su vida privada; la «star as professional», un concepto aplicable a aquellas estrellas que, en función de sus rasgos personales y de su temperamento propio, están catalogadas en una determinada clase de papeles e interpretan personajes similares en todas sus películas (Julia Roberts, Arnold Schwarzenegger); por último, la «star as performer», que se distingue por su talento artístico y crea un personaje distinto en cada película (Meryl Streep). Christine Geraghty, «Re-examining Stardom: Questions of Texts, Bodies, and Performances», en Christine Gledhill y Linda Williams (dirs.), Reinventing Film Studies (London, Arnold, 2000), pp. 183-201.

[26] César Arconada, Vida de Greta Garbo (Madrid, Miguel Castellote, 1974), pp. 223-224. 


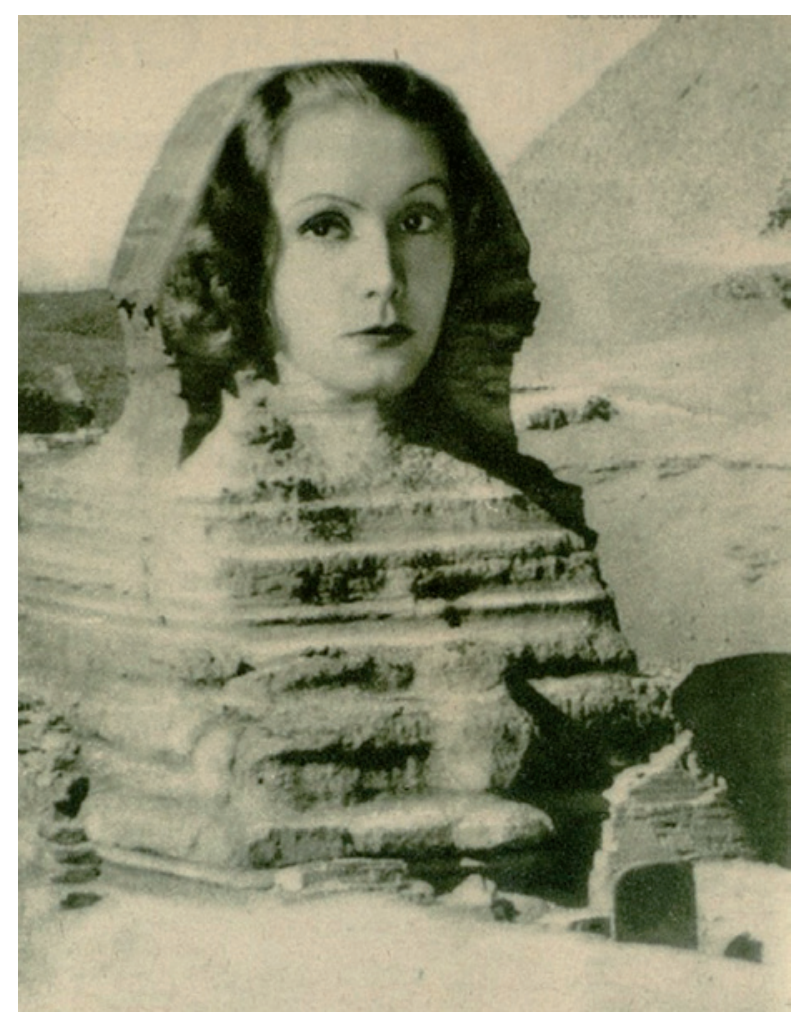

«La esfinge sueca» (Films Selectos, n. $^{\circ}$ 100, 10 de septiembre de 1932) corazones jóvenes y fue la causa de que muchas esposas empezaran a comprender que no se habían casado por amor y que la felicidad, muchas veces, se esconde en lo imposible y en lo prohibido... ${ }^{27}$.

Volveremos sobre este aspecto. De momento, queremos subrayar la idea de «omnipotencia demiúrgica» que se desprendre del comentario de Arconada y que, a finales de los años veinte, se impuso como propiedad intrínseca de la actriz y como parte de su imagen de estrella. De forma previsible, la omnipotencia demiúrgica de estrellas de sexo femenino como Greta Garbo no hubiera podido ser aceptada sin restricciones en la medida en que la esfera de la creación siempre se había visto como territorio masculino. En la literatura y las artes pictóricas, la mujer podía ser el objeto de la creación, musa, inspiradora, pero no autora de la obra ${ }^{28}$. Pero, precisamente, en el caso de una película, ¿quién era el autor? Hemos aquí una pregunta clave para explicar unos fenómenos que empezaron a surgir a finales de los años veinte y que iban a marcar la prensa de los años treinta, convirtiéndola en un verdadero campo de batalla. El estudio de la recepción de Greta Garbo resulta idóneo para dar cuenta de ello, puesto que esta estrella fue el catalizador de las tensiones que el cine y sus estrellas provocaron en España por aquel momento.

[27] Santiago Aguilar, «La vida amorosa de Greta en la pantalla. John Gilbert: el amante de ficción que quiere ser amante de verdad» (Cinegramas, n. ${ }^{\circ}$ 13, 9 de diciembre de 1934).

[28] A este respecto, véase Michelle Coquillat, La poétique du mâle (París, Gallimard, 1982).

[29] Para una caracterización de las publicaciones cinematográficas del primer tercio del siglo xx, consúltese Aitor Hernández Eguíluz, Testimonios en huecograbado. El cine de la $2^{a}$ República y su prensa especializada (1930-1939) (Valencia, Ediciones de la Filmoteca, 2009).

\section{La prensa cinematográfica como campo de batalla. ¿Quién es el au- tor del film?}

En su inmensa mayoría, la revistas cinematográficas que se venían publicando desde los años diez eran revistas «híbridas» que incorporaban todo tipo de material: críticas o reseñas de películas, artículos técnico-profesionales, entrevistas a actores, fotografías, chismes, etc. Popular Film, una de las publicaciones más relevantes del primer tercio del siglo xx, nació con la óptica de proporcionar a sus lectores un contenido variado, con el fin de responder a las inquietudes más diversas. Dentro de esta hibridez, el star system era la piedra de toque del carácter popular de la revista cinematográfica. Por supuesto, cada publicación tenía sus peculiaridades y características propias, pero la mayoría cabía dentro de este modelo «híbrido» que correspondía a la voluntad de alcanzar un público lector amplio y diverso ${ }^{29}$. 
A principios de los años treinta, un grupo de críticos trató de imprimir otro toque a esta prensa polimorfa, purificándola de sus facetas más «frívolas» y emprendiendo un verdadero combate contra las estrellas. Se trata principalmente de aquellos críticos que formaron parte de la llamada «generación de Popular Film» (GPF), denominación forjada por Alberto Mar según el cual esta «generación» abarcaba «desde Gómez Mesa a Joaquín Vega y Mario León, pasando por [Antonio del Amo] Algara, Castellón Díaz, Serrano de Osma, Carrasco de la Rubia, Mariano de Alcázar, Perales, Juan M. Plaza, Luis M. Serrano, Augusto Ysern, Pedro Sánchez Diana, J. G. de Ubieta, Pedro Álvarez, Guzmán Merino, Rafael Gil y Alberto Mar»30. Según Alberto Mar, las afinidades compartidas por estos críticos abarcan: su admiración por el cine soviético; el combate contra la guerra, la censura, el capitalismo y la estrella; cierto «anarquismo» en la forma de defender sus ideas; y la promoción del cine nacional. Para algunos de ellos, el entusiasmo por el cine soviético se relaciona con decisiones políticas, en particular la adhesión al Partido Comunista. A veces, semejante orientación no será más que una efímera experiencia juvenil, ya que, luego, Carlos Serrano de Osma, Antonio del Amo y Rafael Gil pondrán sus fuerzas al servicio de la causa franquista.

Algunos críticos de la GPF colaboraban también en otras publicaciones, de modo que sus ideas se extendieron a la prensa cinematográfica en su globalidad, con un grado variable en función de los títulos. Por ejemplo, Guzmán Merino y Del Amo colaboran en Cinegramas; Del Amo, Plaza, Serrano de Osma, Gil y Gómez Mesa en Nuestro Cinema, la revista antiestrella por antonomasia, dirigida por Juan Piqueras, el «Delluc español» según el mote que le dio Georges Sadoul. Militante del Partido Comunista, Piqueras vivía desde 1930 en París, donde se editaba la revista antes de imprimirse en Barcelona. Nuestro Cinema alcanzará un total de diecisiete números, publicados en dos épocas: junio de 1932-octubre de 1933 (trece números) y enero-agosto de 1935 (cuatro números).

Por supuesto, la voluntad de privilegiar el cine soviético - en el cual no hay estrellas - contra el cine de Hollywood - cuyo éxito estriba en el star system- se debe a un contexto político marcado por el auge de la lucha de clases. Sin embargo, es posible pensar que detrás de este motivo se esconden otras inquietudes menos explícitas y menos confesables.

En los albores de los años treinta, el cinematógrafo estaba pasando por una etapa fundamental que sellaría su condición de «séptimo arte»: se trata del proceso de legitimación artística y cultural del cine que, en sus inicios, no era más que un espectáculo callejero y que, ya por los años veinte, había llegado a formar parte de la vida cultural de la sociedad española, despertando el interés de los intelectuales. Este proceso de legitimación artística era indisociable de la búsqueda y nominación de un «autor del film». Con arreglo al modelo de la literatura y de las artes pictóricas, el cine necesitaba encontrar a su «padre», es decir, a su creador, para ser reconocido como arte. Hasta finales de los años veinte, seguía existiendo una fuerte indeterminación frente a la [3o] Alberto Mar, «Carta abierta a Rafael Gil... sobre la "generación" de Popular Film...» (Popular Film, n. ${ }^{\circ}$ 517, 16 de julio de 1936). 
[31] En territorio hollywoodiense, el autor sería más bien el productor, mientras que en Europa y, en particular, en Francia, donde la figura del «autor-creador» es sagrada en las artes, es ante todo el «director» el que ha de llevarse el título. Véase Martine Chaudron, «Pourquoi la catégorie "film d'auteur" s'impose-t-elle en France précisément?» (Sociologie de l'Art, vol. 11 \& 12, n. ${ }^{\circ} 1$, 2008), pp. 101-138.

[32] Edgar Morin, p. 8o. cuestión de quién era el autor de una producción fílmica y, entre los distintos agentes que intervenían en la concepción de una película, no se sabía muy bien a cuál de ellos otorgar el título. En el caso de las películas de Hollywood, el tema era aún más complicado debido a una concepción distinta de la autoría cinematográfica ${ }^{31}$.

Si la «política de autores» es un concepto que fue forjado en 1955 por el crítico y cineasta François Truffaut y que se vincula ante todo a la Nouvelle Vague francesa, hay que subrayar que esta política ya había sido iniciada anteriormente, en los años treinta, por algunos intelectuales que eran figuras destacadas en la cultura cinematográfica francesa de aquel periodo. Louis Delluc, Germaine Dulac, Marcel L’Herbier, Jean Epstein o René Clair ya habían hecho todo lo posible para que adviniera un «cine de autor» y luchaban arduamente por el reconocimiento del realizador como autor del film. No solo por influencia francesa, sino también por motivos específicos, la prensa española lleva la impronta de esta «política de autores» avant la lettre, que se patentiza en particular en Nuestro Cinema y Popular Film.

Ahora bien, como se ha dicho anteriormente, algunas actrices, en particular aquellas cuya carrera se desarrollaba dentro del star system norteamericano, eran capaces de imponerse en la pantalla hasta el punto de crear la impresión de que ellas eran las autoras de sus películas. Con las estrellas y, con más razón, en el caso de las stars as performers como Garbo, la creación dejaba de ser una prerrogativa masculina y se feminizaba. Desde luego, una estrella podía ser de sexo masculino, pero, como lo subraya Morin, «la preponderancia femenina da al star system un carácter femenino. [...] Nuestras descripciones de la estrella han sido hechas a menudo en femenino. Hemos feminizado, naturalmente, a la estrella, palabra, ella misma, femenina» ${ }^{22}$.

La carta de un lector publicada en 1928 en La Pantalla muestra que, ya a finales de los años veinte, se intentaba educar al público, dándole a entender que el autor de una película no era su intérprete, por muy talentoso que fuera, sino el «director», palabra que coexistía con otros términos que hoy en día se siguen empleando («cineasta», «realizador») y otros que han caído en desuso, por lo menos para remitir al autor de la cinta («animador»). Afirma este lector lo siguiente:

Creen los cinematografistas que ese apasionamiento excesivo, loco, del público por los artistas de la pantalla es lo que da «vida» al séptimo arte, obteniéndose por doquier grandes éxitos de taquilla con cintas regulares o detestables, por el solo hecho de ser interpretadas por cualquier astro de los de primera magnitud, favorito del público. Sin embargo, ese apasionamiento es lo que «mata» al cinematógrafo moralmente mientras le da una vida ficticia, artificial, que engaña a los cinematografistas y a los cineastas verdaderos.

Hoy, gracias al haber salido del incógnito producteurs, técnicos, etc., mostrándose al público, y gracias también, en España, a la presente revista, que «instruye» al lector inculcándole la verdadera cinematografía -el arte y la técnica de la cinematografía-, empezamos a saber que para impresionar una película no solamente es necesaria una pareja de bellos artistas, sino que esta es solo 
un complemento -importantísimo, no obstante- de los varios elementos iniciales e imprescindibles para toda producción. Y vamos sabiendo que si los intérpretes obran de tal o cual modo, conduciendo la «farsa» a una situación o a otra, no es obedeciendo a su capricho ni improvisando con su graciosa inventiva, sino que siguen la pauta que de antemano ha ideado y compuesto $e x$ profeso un «argumentista». Y aun dentro de esta ruta trazada, aquellas bellas figuras se mueven a la voz de mando de un «director», que ha de cuidar de la colocación, movimientos, decorados, luces y «trucos», procurando el mejor efecto artístico y técnico posible ${ }^{33}$.

Esta carta atestigua la escisión que se está formando entre la «verdadera cinematografía» que corresponde a una lectura correcta, adecuada, del fenómeno cinematográfico y otra forma - errónea- de entender el cine, consistente en creer que son los intérpretes los que construyen la cinta. La asimilación del autor de cine al «director» constituye, pues, la clave de la distinción cinéfila. El lector estigmatiza al público que sigue creyendo en la supremacía de los intérpretes y presenta a estos como meros «complementos», es decir, como auxiliares que se reducen a acatar las órdenes del «director». La existencia de esta palabra en inglés y en español - cuando es en francés, por ejemplo, solo se emplean los términos «réalisateur» o «cinéaste», que son más neutros - tiene importantes consecuencias, ya que incorpora la idea de superioridad y establece una relación entre el hecho de ser el autor de una película y el ejercicio del poder.

Estos fenómenos que impregnan la cultura cinematográfica española han de ponerse en relación con la evolución inédita que la condición femenina iba conociendo en España, tanto más cuanto que la tendencia aludida se acentuaría fuertemente durante los años treinta, ya bajo la Segunda República, cuando se adoptó el derecho al voto de las mujeres y la ley de divorcio en 1932.

La defensa a ultranza del cine ruso o soviético que caracteriza los miembros de la GPF o incluso la preferencia por unas cinematografías europeas como la alemana, permite redistribuir los papeles y reafirmar la condición del concepto de creación como propiedad masculina. La glorificación de cinematografías sin estrellas tiene la enorme «ventaja» de modificar ciertos usos y costumbres: en adelante, ya no se dirá «un film de Greta» o «un film de Marlène», sino «un film de Eisenstein» o «un film de Poudovkin».

El debate en torno al autor del film cobró tal intensidad que preocupó a quienes eran más afines a la literatura, como el crítico Antonio Guzmán Merino, que deploró la actitud extrema de «los cineístas con olor de santidad, místicos del celuloide, [...] transverberados por las llagas del Séptimo Arte, [que] sufren raptos y deliquios amorosos ante un fotograma de Eisenstein, y [...] escriben canciones espirituales entre el cineísta y el realizador ${ }^{34}$ ». El léxico empleado muestra hasta qué punto el «director» constituye para estos críticos una figura divina y hasta un ideal viril y espiritual que ellos contraponen a la materialidad frívola de las estrellas femeninas ${ }^{35}$.
[33] Carta de José Torrella, «El alma del cine» (La Pantalla, n. ${ }^{\circ}$ 26, 18 de noviembre de 1928).

[34] Antonio Guzmán Merino, «Hace falta un heresiarca» (Popular Film, n. ${ }^{\circ} 419,23$ de agosto de 1934).

[35] Sirvan de ejemplo estos comentarios de Pedro Sánchez Diana: «El cineasta verdadero, no el componente de la recua que habitualmente constituye el público, saborea con sibarítico placer toda realización de sus ídolos, que no solo son artistas, sino directores. Basta en mí ver un film realizado por un nombre pleno de garantías cinemáticas, como Lang, Vidor, Pabst..., para acudir sin pérdida de tiempo al estreno. [...] Es necesario saber llegar al alma de sus realizadores para comprender en verdad un film. Así, nosotros consideramos como magos del cinema, no solo a artistas, sino a realizadores. En mi cuarto, al lado de Conrad Veidt, hallaría el lector a Von Stroheim y, así sucesivamente y por todo el mundo, no pondría en mi cuarto una fotografía de $\mathrm{Mu}$ rray Anderson. La personalidad de los directores es mucho más interesante y cinemática que saber el número de veces que Pola Negri se ha casado o que el número de zapatos que posee Janet MacDonald [...]». Pedro Sánchez Diana, «Realizadores e intérpretes, I» (Popular Film, n. ${ }^{\circ}$ 30o, 12 de mayo de 1932). 
[36] Esta expresión se encuentra en un artículo de Sánchez Diana: «El cinema lo ha captado todo; todo ha quedado bajo su dependencia. Las artes, que antes le ayudaban, son ahora ayudadas por él [...]. Hoy no hay cuadro que pueda llegar al grado de perfección visual a que ha llegado Dovchenko. [...] Es necesario que esos magos del nuevo arte, Lang, Pabst, Vidor [...] sigan impulsándolo hacia su triunfo. Hoy día se dice Miguel Ángel, Murillo; mañana las generaciones venideras dirán Fritz Lang, Erich Pommer, como garantía de perfección artística y cinemática y, el día de mañana, no se dirá jamás séptimo arte ni cinema; se dirá solamente primer arte, y ojalá que haya un día que se diga Único Arte». Pedro Sánchez Diana, «Primer Arte», (Popular Film n. ${ }^{\circ} 303,2$ de junio de 1932).

[37] Antonio Guzmán Merino, «Hace falta un heresiarca».

[38] Michelle Coquillat, La poétique du mâle, p. 157.

[39] Noël Burch, «Des effets pervers de la notion d'auteur», en Noël Burch y Geneviève Sellier, Le cinéma au prisme des rapports de sexe (París, Vrin, 2009), pp. 91-105.

[40] Nerea Aresti Esteban, Médicos, donjuanes y mujeres modernas: los ideales de feminidad y masculinidad en el primer tercio del siglo XX (Bilbao, Universidad del País Vasco, 2001), p. 71.

[41] Rebecca Bell-Metereau, Hollywood Androgyny (New York, Columbia University Press, 1985), p. 70.
Este culto al realizador reflejaba el afán de que el cine llegara a superar a las demás artes hasta imponerse como «único arte» ${ }^{36}$, de ahí la oposición de Merino, que intentó hacer entrar en razón a sus camaradas: «como si la literatura, amigo Algara, entendida en sentido de creación poética, no precediera a todos los partos cinematográficos» ${ }^{37}$. La imagen del parto indica hasta qué punto, por aquel entonces y en las décadas posteriores, la creación respondía a un criterio de género: mientras la mujer daba a luz conforme a una función puramente biológica que la situaba en la esfera de la materia, el hombre también "paría», pero el objeto de su parto era una creación espiritual. Es lo que Coquillat denomina «el parto creativo del varón» ${ }^{8}$.

La sacralización de la figura del autor en las artes y la literatura entronca con una tradición europea que, como ha mostrado Noël Burch ${ }^{39}$, se remonta al Romanticismo y asocia la creación y la trascendencia al género masculino mientras que lo femenino queda circunscrito a lo material y a la reproducción. En la prensa cinematográfica española, esta tradición entra en colisión con el star system, lo que ha de interpretarse según parámetros variados y complementarios: el proceso de legitimación artística del cine, el auge de la lucha de clases y la decisión de defender películas que representen las masas en vez de promocionar una estrella, pero también la voluntad de oponerse al poder que la pantalla otorga a las estrellas femeninas en un momento en que la condición femenina estaba conociendo avances inéditos. Tanto más cuanto que, a principios de los años treinta, estas estrellas se volvieron aún más problemáticas debido a la aparición del cine parlante, que las desidealizó y acentuó su carácter desviante respecto a los cánones tradicionales de feminidad. Una vez más, esto se comprueba muy bien con el ejemplo de Greta Garbo.

\section{La ambigüedad sexual de las estrellas: ¿un elemento esencial?}

Aunque la sociedad española de los años treinta fue el escenario de una «renegociación de las bases sobre las que se sustentaban las relaciones entre hombres y mujeres ${ }^{40}$, la ambigüedad sexual seguía siendo inaceptable y unos ideólogos como Marañón o Juarros, que intervinieron en los debates progresistas en torno a la condición femenina, insistieron en la necesidad de preservar la «diferenciación sexual», una noción estrechamente vinculada a la conservación de la norma heterosexual.

Estas reservas chocaban con la orientación que cobrarían no pocas películas hollywoodienses rodadas entre 1930 y 1934. Durante este periodo, es frecuente ver en las pantallas a mujeres masculinizadas, lo que se debe en particular al contexto socio-económico: tras el colapso bursátil de 1929, numerosas mujeres tuvieron que incorporarse al mundo laboral, de modo que las películas pudieron incorporar a mujeres fuertes y masculinas como modelos positivos ${ }^{41}$.

La androginia y la construcción de la imagen de Garbo como mujer moderna ya se transparentan en sus películas mudas, pero se vuelven aún más patentes con el paso al cine parlante. Hay que subrayar que, si el cine de 
Hollywood se caracterizaba desde sus orígenes por una ambigüedad textual que responde a una necesidad comercial ${ }^{42}$, esta dimensión se vio acentuada por el Crac del 29, dando lugar, hasta 1934, a la era del women's film: conscientes de que las mujeres constituían una parte importante - sin duda mayoritaria - del público cinematográfico, las casas productoras, deseosas de asegurar su supervivencia, se mostraron complacientes con el público femenino y propusieron guiones que «planteaban la cuestión de la identidad femenina dentro del patriarcado» ${ }^{43}$, haciendo caso omiso de la oposición de los sectores conservadores y religiosos.

En Anna Christie, la primera película parlante de Garbo - adaptada de la obra teatral de Eugene O’Neil-, la actriz interpreta a Anna, una fallen woman que cayó en la prostitución tras haber sido violada por uno de sus primos. En la primera secuencia, viene a reunirse con su padre, un marinero que mantiene una relación con Marthy Owen (Marie Dressler), una anciana alcohólica. Vestida con sobriedad, con una maleta en la mano, Anna aparece por primera vez en la puerta del bar donde se encuentra Marthy. El cartelito que indica «ladies entrance» introduce un toque irónico habida cuenta del andar y de los modales masculinos de ambas mujeres que, durante toda la secuencia, conversarán con un cigarrillo en la boca y un vaso de alcohol. Al cabo de dieciséis minutos, Garbo pronuncia su primera réplica dirigiéndose al camarero: «Dame un whisky con ginger ale, y no seas tacaño, querido» ${ }^{44}$. Los orígenes suecos del personaje de Anna, igual que el inglés popular y con argot de los diálogos, habían de justificar el acento de Garbo y favorecer su paso al cine parlante que, como se sabe, puso término a la carrera de muchas estrellas.

En España, el estreno de Anna Christie tuvo lugar el 20 de noviembre de 1930 en el cine Callao. A pesar de que se habían agotado las entradas para las primeras sesiones, la película solo permaneció cuatro días en la cartelera madrileña. El crítico Hernández Catá se hizo eco de la muy mala acogida que tuvo:

Greta Garbo, la gran actriz sueca, acaba de ser repudiada en cien salas de espectáculos por las muchedumbres, que habían hecho de ella su querida. Tan unánime condenación no le ha sobrevenido por realizar un acto de superperversidad o por haberse convertido a una honestidad fofa. Bastole hablar unas cuantas palabras. No había dicho en la película Anna Christie más de veinte y ya la desilusión y la infidelidad se aliaban contra ella ${ }^{45}$.

En su artículo, el crítico trataba de encontrar circunstancias atenuantes que pudieran explicar lo desagradable de esta voz, echando la culpa a la mala calidad de los equipos sonoros. También subrayaba la adecuación entre esta voz y la del personaje interpretado:

La actriz sueca ha presentado y hablado a Anna Christie sin adulteraciones y no ha vacilado en dejar que una voz indigna de ella fuese a pinchar con sus aristas los millares de globos de ilusión elevados en toda la tierra por su figura de mujer fatal.
[42] Por la certeza que tenían los productores de que las mujeres desempeñaban un papel decisivo en el éxito o fracaso comercial de una película en el mercado interior. Noël Burch, «Double Speak. De l'ambiguïté tendancielle du cinéma hollywoodien", (Réseaux, vol. 18, n. $\left.{ }^{\circ} 99,2000\right)$, p. 112.

[43] Isabelle Dhommée, Les cinq «empoisonneuses»: G. Garbo, J. Crawford, M. Dietrich, M. West, K. Hepburn et les États-Unis des années trente. Analyse du phénomène social de la star (Tesis doctoral, Paris, Université Sorbonne Nouvelle Paris III, 2000), p. 370 .

[44] «Gimme a whiskey, ginger ale on the side, and don't be stingy, baby».

[45] Alfonso Hernández-Catá, «La voz de Greta Garbo» (La Voz, 3 de diciembre de 1930). 
No, ciertamente, no es seductora la voz de Greta Garbo en Anna Christie, como no es seductora ninguna de las voces embalsamadas hasta hoy en el cinematógrafo sonoro. Les falta intimidad, les sobra volumen, adherencias. Todas tienen algo de ronquido, cual si pulmones hervorosos palpitaran debajo de unas cuerdas vocales siempre desafinadas ${ }^{46}$.

De hecho, esta primera cinta parlante confirmó la «masculinidad» de Garbo de dos maneras: por una parte, quedó reforzado su estatuto de star as performer -es decir, de mujer creadora-, ya que la actriz había interpretado a Anna Christie con profesionalismo, con una voz acorde con la procedencia social del personaje; al mismo tiempo, los públicos pudieron oír una voz que no coincidía en absoluto con el glamour que Hollywood había fabricado en las primeras cintas.

En este contexto, tratándose del público masculino, el hecho de sentirse atraído por una estrella como Garbo se volvió vergonzoso y pudo interpretarse como síntoma de una tendencia homosexual latente, de ahí el intento por erradicarla. De hecho, la homosexualidad es el otro espectro que los críticos intentan exorcizar llevando a cabo la lucha contra las estrellas, no solo femeninas, sino también masculinas.

A estas alturas, se ha explicado el combate contra la estrella en función de la capacidad de esta para usurpar el título de autor de la obra, posibilitando el hecho de que la creación artística deje de ser una prerrogativa masculina para ser ejercida también por mujeres. ¿Qué ocurre, pues, en el caso de las estrellas masculinas que también pueden acaparar la pantalla y hacer que los demás agentes caigan en la invisibilidad total?

Los críticos que intentaron depurar la cultura cinematográfica de sus elementos más indeseables como las estrellas habrán sentido cierta incomodidad frente a la ambigüedad sexual que se desprendía también de las estrellas masculinas. Por definición, la estrella pasa por un proceso de estilización de su físico que implica una elegancia y un refinamiento contrarios a la virilidad. En su estudio sobre Don Juan, Marañón destaca las características físicas y morfológicas de lo que él llama el «prototipo varón», las cuales han de ser más bien antiestéticas. Preconiza Marañón una «piel dura y muy provista de barba y vello» ${ }^{47}$. Los hombres del cine ruso corresponden perfectamente a este ideal de virilidad que se opone al Don Juan afeminado que describe Marañón, ese «Don Juan esbelto, elegante, de piel fina, cabello ondulado y rostro lampiño o adornado de leve barba puntiaguda» ${ }^{48}$, cuya feminidad radica también en «el

\section{[46] Íbid.}

[47] Gregorio Marañón, Don Juan (Madrid, Espasa-Calpe, 1976), p. 77.

[48] Íbid.

[49] Íbid. cuidado minucioso de su vestido y, a veces, [en] la llamativa exageración de este, [que] acentúan todavía más esta borrosidad de lo viril en la morfología donjuanesca» ${ }^{49}$. Estas características «feminizantes» las posee también la estrella, en la cual la barba - muy prominente en el cine ruso- ha desaparecido en favor de un rostro barbilampiño. El tema del bigote, por cierto, se convirtió casi en una obsesión. El periodista Luis Champín Antoli da buen ejemplo de ello al describir con amargura este cambio inducido por la pantalla: 
¿Quién habría de decirnos que la mayoría de los hombres civilizados cortarían la punta de sus bigotes, que fueron signo de virilidad, reduciéndolas a la ridícula expresión de una manchita bajo la nariz? [...] Y después, la navaja barbera segó el rastrojo bigotáceo, dejando las caras lampiñas como la de los principales artistas mudos; y sus trajes chulos y sus actitudes desafiadoras sirven de modelo a los «niños-pera» que pasean su insolencia por los bulevares, como si anduviesen por las peligrosas estepas americanas [...]. Atentos solo a lo que enseña la mudez de la pantalla cinematográfica, después de observar los tipos que más fascinan a las mujeres, los imitan para sustituirlos en la vida; y aquellos que, por esnobismo, no quieren seguir la corriente general, quedan atrás como los fósiles de las edades geológicas ${ }^{50}$.

El texto de Buñuel titulado «Variaciones sobre el bigote de Menjou», también publicado en 1928, expresa la amargura que buena parte del público masculino habrá experimentado frente a esta «manchita bajo la nariz» y al refinamiento antiviril del actor. Incluye irónicamente los comentarios que Buñuel presta a una de sus parejas fílmicas, según la cual el bigote de Menjou no irrita la piel y produce «un cosquilleo delicioso e inconfesable, muy apreciado por nosotras ${ }^{51}$.

Sin duda, el estereotipo que mejor encarnaba esta feminidad de la estrella de sexo masculino era el latin lover, un modelo que era aceptable para un público masculino estadounidense, que lo contemplaba como un «otro» exótico, pero que podía resultarle insoportable al público latino, que se negaba a verse representado bajo esos rasgos. Rudolph Valentino, el primer actor que encarnó al latin lover, gozaba de una popularidad inmensa entre las mujeres, lo cual se debía a sus disposiciones supuestamente "femeninas» como la ternura, la pasividad y la empatía que era capaz de demostrar hacia a sus parejas fílmicas ${ }^{52}$.

De hecho, los críticos que expresaron su afición por las estrellas etiquetadas como latin lovers se vieron estigmatizados por los críticos de la GPF y por Piqueras. Fue así como Augusto Ysern proclamó la «muerte cinemática» de Rafael Martínez Gandía, quien solía dedicar sus artículos al star system:
[50] Luis Champín Antoli, «El cine revoluciona al mundo, I» (Popular Film, n. ${ }^{\circ} 116,18$ de octubre de 1928).

[51] Luis Buñuel, « Variaciones sobre el bigote de Menjou » ( $L a$ Gaceta Literaria, n. ${ }^{\circ} 35$, junio de 1928).

[52] Miriam Hansen, "Pleasure, Ambivalence, Identification: Valentino and Female Spectatorship», en Christine Gledhill (dir.), Stardom: Industry of Desire (London, Routledge, 1991), pp. 259-282. Véase también Loredana Leconte, "Latin Charm. Inventing Rudolph Valentino», en Giannino Malossi (dir.), Latin Lover: the Passionate South (Milan, Charta, 1996), pp. 81-93.



Amparo Verardini, «¿Es peligroso ser guapo? Las desventuras de algunos bellos galanes de "cine"» (Estampa, n. ${ }^{\circ}$ 92, 15 de octubre de 1929) 
[53] Augusto Ysern, «MadridCinema. Ecos y comentarios comprimidos» (Popular Film, n. ${ }^{\circ} 329,1$ de diciembre de 1932).

[54] Arturo Casinos Guillén, «Desorientación en las masas» (Popular Film, n. ${ }^{\circ} 343,9$ de marzo de 1933).

[55] Pedro Sánchez Diana, "Gestas del cinema» (Popular Film, n. ${ }^{\circ}$ 412, 5 de julio de 1934).

[56] Antonio Guzmán Merino opta también por el cine soviético en uno de sus editoriales en el cual expresa el deseo de que el cine se convierta en un «arte universal, de emociones incorporadas en síntesis, verdadero latido del corazón de la multitud, arte político en su acepción más noble». Ahora bien, este cine político ha de excluir ciertos elementos problemáticos: «El cine que no debe ser operetas, ni dramas policiacos, ni vampiresas, ni "gangsters", ni disimuladas evocaciones de Sodomas y Gomorras, oxigenadas y barbilampiñas. Aunque las doncellas impacientes de dejar de serlo y los galanes afeminados y cineastas que las escoltan [...] nos excomulguen, propugnamos un cine político que arroje esa inmundicia heredada de la impotente escuela del "arte por el arte”». Antonio Guzmán Merino, «¿A qué ha venido el cine?, I» (Popular Film, n. ${ }^{\circ}$ 358, 22 de junio de 1933).

[57] Pierre Albertini, «Une tradition étrangère à la classe ouvrière» (Les mots sont importants, 10 de noviembre de 2012). Disponible en: <http:// Imsi.net/Une-tradition-etrangere-a-la $>$ (20/02/2017).

[58] Dominique Fernandez, Le rapt de Ganymède (París, Grasset, 1989).
Rafael Martínez Gandía ha muerto cinemáticamente para todos los hombres de sentido común que forman la crítica de cine. [...] Su última voluntad fue rogar obstinadamente, a toda su familia y amigos, que no fueran a ver películas rusas en todo lo que les quedara de vida. [...] Prefirió morirse en noviembre, porque no le gustaba Octubre. Le gustaba José Mojica [...]. Descanse en paz el envenenador de cuartillas y de juventudes que fue director de la A. E. C. Q. N. H. Q. L. S. N. E. B. (Asociación de escritores cretinos que no hay quien los soporte ni en broma). [...] Desde que murió siempre ha habido una visita en su tumba. Últimamente, una modistilla pizpireta y Greta Garbo se han pasado varios días llorando ante su sepultura, pidiendo a Dios por el alma de este malogrado «Rodolfo», que colaboró en Crónica y cuyas incongruencias hicieron eco en el diario $L a V z^{53}$.

Otro artículo de Arturo Casinos Guillén sigue la misma dirección y arremete en particular contra el público masculino joven que imita a las estrellas masculinas feminizadas, oponiendo como contraejemplo su preferencia por los directores:

¿Y quién es ese público que tan abiertamente rechaza el cinema de avance o vanguardista? [...] iAh lector!, ese público que tanto se distingue por su vulgaridad está compuesto por unos cuantos jovencitos, mal llamados «señoritos», que sueñan con emular las «glorias» de un Mojica, o de un Chevalier, o de un Robert Montgomery; está integrado por todos esos jóvenes que ignoran quién es un Pabst, un Niblo, un Eisenstein, un Pudovkin... y, por el contrario, conocen al dedillo cuántas veces se ha divorciado Clara Bow, quién es el afortunado esposo de Joan Crawford, de qué color son los ojos de Joan Crawford, de qué color son los ojos de Marlene Dietrich, a qué hora se levanta Greta Garbo y otras idioteces por el estilo ${ }^{54}$.

Los críticos antiestrellas se posicionan, pues, a favor de las masas y condenan el cine de Hollywood por su dimensión «burguesa», es decir, por el ambiente idealizado en que se desarrolla la acción, con decorados lujosos y personajes ociosos. Hay que recalcar, sin embargo, el sentido que estos críticos confieren al término «burgués»:

Arte creado para las masas debe ser por ellas y para ellas encauzado honrada, pura, noblemente.

Y el cinema no debe ser para el burgués; debe ser para todos, comprendido por todos y sobre todo dignamente.

Es decir, sin films homosexualizantes como Boliche, o los de Mojica ${ }^{55}$.

Este vínculo entre la dimensión «burguesa» de las películas de Hollywood y la homosexualidad aparece en otros textos ${ }^{56}$. Desde finales del siglo xIx, la homosexualidad se vinculaba a las clases sociales superiores y constituía, según Pierre Albertini, una «tradición ajena a la clase obrera», un «vicio de las élites ${ }^{57}$. Estaba vista como una consecuencia del sistema capitalista que propagaba el lujo, vector de decadencia moral. El régimen patriarcal y homófobo de Stalin la presentó como un "producto de la decadencia burguesa», «una perversión fascista» a la cual opuso la «pureza moral» del proletariado ${ }^{58}$. El Código Penal de 1931 castiga la homosexualidad con penas de cárcel y deportaciones al gulag. 
En España, la homosexualidad estaba en el centro de los debates sociales $\mathrm{y}$, a pesar de unas inflexiones legislativas ${ }^{59}$, todavía se la consideraba como una plaga que combatir, estigmatizando a quienes expresaran su afición por las estrellas sexualmente ambiguas ${ }^{60}$.

Los mecanismos descritos permiten entender mejor los motivos que llevaron a algunos críticos a combatir las estrellas como Garbo o como Valentino -y otros actores que prolongaron el linaje del latin lover (Ramón Novarro, John Gilbert) - que hacían que los límites entre lo femenino y lo masculino se desdibujaran, causando una verdadera psicosis, sobre todo por el poder de influencia que tenían en los públicos. El examen de esta influencia en las espectadoras completará el análisis.

\section{Greta Garbo y el público femenino}

En su estudio de las relaciones que se tejieron entre las espectadoras británicas y las estrellas de los años cuarenta y cincuenta, Jackie Stacey propone dos esquemas teóricos para analizar la identificación de aquellas con estas. Destaca primero las «fantasías identificatorias» («identificatory fantasies») -categoría que se vincula ante todo a la imaginación-y las «prácticas identificatorias» («identificatory practices») -conjunto de actividades que corresponden a una utilización cultural de la estrella- ${ }^{61}$.

El segundo esquema incluye, por una parte, la «identificación cinemática» («cinematic identification») - restringida al espacio-tiempo de la proyección- y, por otra, la «identificación extra-cinemática» («extra-cinematic identification»), que se relaciona con un más allá de la proyección. La «identificación cinemática» pertenece a la esfera de la fantasía y la imaginación; incluye impresiones y emociones que la espectadora siente en su fuero interno y que su entorno no percibe de forma evidente. Se trata de fenómenos como la adoración, el hecho de considerar a la estrella como si fuese un ente superior, el afán de llegar a ser como ella. Por el contrario, la «identificación extra-cinemática» se vincula con la práctica y con hechos visibles; implica la existencia de usos que el entorno sí puede percibir y que incluso implican reacción o participación de su parte, de modo que esta segunda forma de identificación tiene un carácter socializante. Las prácticas que Stacey incluye dentro de esta categoría implican la transformación física y/o moral de la espectadora que, bajo la influencia de la estrella, modifica su comportamiento o su apariencia. El hecho de «ser como la estrella» ya no se reduce a un mero deseo, sino que provoca el uso de determinados medios con el fin de parecerse a ella y apropiarse del ideal femenino que encarna. De esta manera, la espectadora crea una nueva identidad femenina.

La cultura cinematográfica de los años veinte y treinta atestigua la existencia de esos fenómenos en el público femenino español, en particular del público joven en busca de personalidad propia y en pleno proceso de construcción de su identidad.
[59] En España, el Código Penal de 1928 condenaba la homosexualidad con multas que iban de mil a diez mil pesetas. A principios de los años treinta, la medicina social luchó por el abandono de esta legislación y presentó la homosexualidad, no como un delito o un crimen, sino como una patología. La Segunda República abrogó el Código Penal de 1928 y la condena eventual de los actos homosexuales dependió en adelante de la Ley de Vagos y Maleantes, adoptada en agosto de 1933 , que castiga a los individuos «antisociales» (mendigos, toxicómanos, alcohólicos, rufianes, prostitutas). Será aplicada para reprimir la homosexualidad en 1935 y luego bajo el franquismo. Nerea Aresti Esteban, Masculinidades en tela de juicio: hombre y género en el primer tercio del siglo XX (Madrid, Cátedra, 2010), p. 227.

[6o] Hasta se pueden encontrar referencias a Marañón en una crítica de Sánchez Diana: «Entre los admiradores del cinema [...] encontramos siempre una gran cantidad de tontos infelices. Nosotros no llamamos infelices a los que se entusiasman con Mojica o Gardel [...]. Estos merecen otra calificación diferente. Calificación digna de ser tratada por Marañón como un caso patológico». Pedro Sánchez Diana, «La usurpadora y su realizador» (Popular Film, n. ${ }^{\circ} 369$, 7 de septiembre de 1933).

[61] Jackie Stacey, Star Gazing: Hollywood Cinema and Female Spectatorship (London, New-York / Routledge, 1994), p. 171. Sin embargo, aunque la identificación con la estrella no se patentice por medio de palabras o modificaciones corporales, el mero hecho de ir al cine para verla constituye de por sí una práctica cultural. Incluso cuando la espectadora no exterioriza sus impresiones ni transforma su apariencia, expresa sus preferencias cinematográficas eligiendo ver una determinada película o, más precisamente, una determinada estrella. 


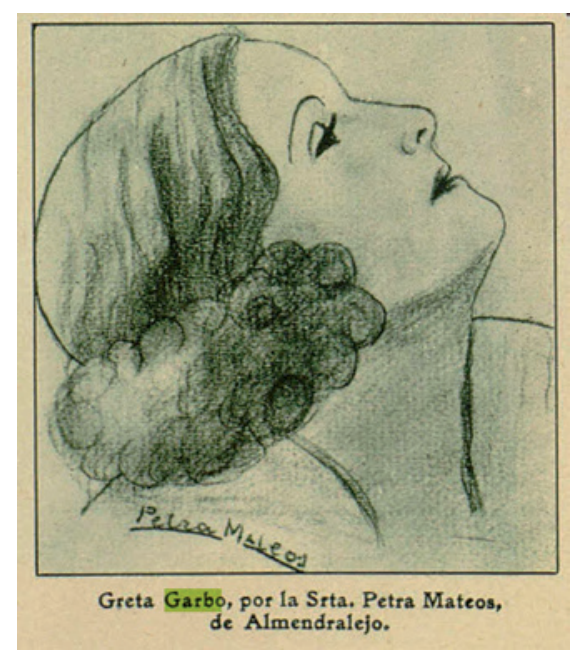

«Dibujantes espontáneos» (Popular Film, n. ${ }^{\circ}$ 243, 9 de abril de 1931)

[62] Este neologismo se parece al término «garboness», acuñado en los fanmazines norteamericanos para aludir a la admiración fuera de lo común que despertaba la actriz y a su extraordinaria popularidad. Sin embargo, hay que subrayar que la sociedad española estaba menos «preparada» que la norteamericana para acoger este fenómeno que no hizo sino acentuar la crisis identitaria que muchos hombres atravesaban por los recientes avances y cambios respecto a la condición femenina. A

este respecto, las comparaciones que la prensa española hizo entre Garbo y Don Juan son muy elocuentes y muestran como, en opinión de muchos, la actriz encarnaba por antonomasia la suplantación de los privilegios que hasta el momento habían sido propiedad de los hombres. Véase, por ejemplo, Fernando de Ossorio, «Greta Garbo y Don Juan» (Popular Film, n. ${ }^{\circ}$ 268, 1 de octubre de 1931).

[63] «Jeanne, la estela de Greta Garbo» (Cinema: revista española, noviembre de 1931).

[64] El comentario de otro periodista transmite la misma idea: «Influye tanto la artista sueca en la actual generación, que hay [...] muchachas que se arreglan las cejas, los ojos, el pelo a lo Greta Garbo. Así, como antes se decía, por ejemplo, esa es una mujer de Penagos, ahora se dice esa es una muchacha a lo Greta Garbo. Y lo cierto es que muchas jóvenes de hoy se parecen a la genial estrella sueca. Es un raro caso de biología que brindamos a los biólogos». Anónimo (Popular Film, n. ${ }^{0}$ 208, 24 de julio de 1930).

[65] En un contexto de promoción de un cine nacional que represente «lo español», el gretagarbismo era una amenaza, como se puede ver en un artículo de Mateo Santos dedicado a la actriz Fuensanta Lorente: «Fuensanta Lorente [...] puede y debe lanzarse a la pantalla sin perder su carácter, sin dejarse desviar por ninguno de esos desorientados directores cuya ignorancia y estupidez se empeñan en que el cinema español sea un calco del cine yanqui o de cualquier otro y que, no pudiendo ellos dirigir a una Garbo, a una Crawford, a una Dietrich, que la artista española pierda el tipo racial, su personalidad, su identificación con el paisaje que la rodea, para parecerse a Marlene, a Joan, o a Greta. Absolutamente estúpido». Mateo Santos, «Muy femenina y muy española» (Popular Film, n. ${ }^{\circ}$ 364, 33 de agosto 1933). Se nota, además, que el mantenimiento del «tipo racial» se inserta dentro de una voluntad de control de la feminidad, que incluye en particular la conservación de una silueta más acorde con los cánones de la feminidad tradicional caracterizada por cierta generosidad en las carnes: «Hasta la aparición de la vampiresa estilo Greta Garbo y de las girls lanzadas en serie al mercado, no acabaron los yanquis en la pantalla con el tipo femenino predominante en el primer cuarto de siglo. Aún es motivo de añoranza para muchos la belleza espléndida y pomposa de Camila Horn y de Vilma Banky, la morenez sazonada y cálida de Pola Negri, la discreta opulencia de Clara Bow y de Mary Brian, últimos figurines vivientes que respondían a un concepto clásico de la estética femenina que llega hasta el siglo xix a través de Grecia y Roma, de las Gracias de Rubens y de la Maja de nuestro don Francisco de Goya y Lucientes» (Íbid.). 
más tranquilizadora de la feminidad. La forma arqueada de las cejas introduce, además, un toque de arrogancia mientras la expresión «andar perezoso y ondulante» describe un movimiento en $\mathrm{S}$, un meneo que se opone a la reserva y a la modestia. En el caso de Garbo, cuyas caderas eran más bien estrechas, este movimiento tenía como efecto llamar la atención hacia lo andrógino de su figura alargada cuyo contoneo es ahora objeto de imitación por parte de las espectadoras. Este elemento viene recalcado en otro artículo dedicado a Garbo y Dietrich, en el cual un periodista afirma que «las muchachas las imitan, depilan sus cejas como ellas, pasan hambre para afinar la silueta, andan varonilmente» ${ }^{66}$.

Por sus características físicas y morales, el gretagarbismo se confunde con el fenómeno de la mujer moderna. En los años que siguieron a la Primera Guerra Mundial, la mujer moderna se vinculó a las muchachas procedentes de la clase media que estaban en contacto con los círculos intelectuales y artísticos y que se rebelaban contra las normas de conducta dictadas por la sociedad. A través de sus reivindicaciones - ambición profesional, afán de autonomía-, de su comportamiento - desprecio de la galantería, cosmopolitismo- y de su apariencia - pelo corto, silueta alargada-, estas muchachas se situaban al margen de la feminidad tradicional y provocaban discursos alarmistas por parte de las élites intelectuales.

Resulta difícil creer que el gretagarbismo llegase a imponerse como fenó-
[66] Fernando Labri, «Estrellas rivales» (Cine-Art, n. ${ }^{\circ} 33$, 30 de mayo de 1934).

[67] Nerea Aresti Esteban, «La mujer moderna, el tercer sexo y la bohemia en los años veinte» (Dossiers feministes, $\mathrm{n}^{\mathrm{o}}$ 10, 2007), p. 176. Disponible en: <http://www.raco. cat/index.php/DossiersFeministes/article/view/102546> (01/03/2017). meno de masas ya que, como se sabe, en España, el modelo de la mujer moderna no afectó a la mayoría de las mujeres, «tal vez ni siquiera a una minoría significativa» ${ }^{67}$. Cabe subrayar, además, que el gretagarbismo se circunscribió a un sector específico del público femenino, el público joven de la clase media, lo que lo acerca al fenómeno de la «chica topolino» de los años cuarenta. En todo caso, es interesante comprobar cómo la influencia - real o fantaseada- de Garbo en el público femenino español provocó discursos alarmistas por parte de las élites intelectuales y cristalizó los miedos provocados por la sombra de la mujer moderna y su implantación en la sociedad española, permitiendo apreciar la hostilidad que se desarrolló en torno a este modelo.

Igual que la mujer moderna, el gretagarbismo suponía una amenaza tremenda de cara al cumplimiento de aquello que se seguía considerando como la función suprema de la mujer: la maternidad. De hecho, pese a los avances que la llegada de la Segunda República supuso respecto a la condición de la mujer, la maternidad era una condición sine qua non que garantizaba el acceso



Sindo, «Garbo y desgarbo de Greta Garbo» (Proyector, n. ${ }^{\circ} 13,15$ de noviembre de 1936). 
[68] «Cil», «Gretagarbismo» (El Sol, 9 de abril de 1933).

[69] Victoria Legido, «De la mujer objeto a la mujer sujeto. Representaciones femeninas en la imagen fotográfica», en Ángela Figueruelo Burrieza et al. (dirs.), Las mujeres en la Constitución europea: estudios multidisciplinares de género (Salamanca, Ediciones Universidad Salamanca, 2005), p. 251.

[7o] Conchita Urquiza, «Conchita Montenegro, reflejo de la ardiente España» (El Cine, 19 marzo de 1931).

[71] Rafael Martínez Gandía, «Rosita Díaz, la bella artista de la pantalla que hubiera querido ser novelista, tiene sus ideas acerca del divorcio y admira a Greta Garbo, la única» (Crónica, 22 de noviembre de 1931). a nuevos derechos y a la protección social. Las protestas que una periodista publicó en la sección «La Mujer, el Niño y el Hogar» del periódico El Sol ilustran muy bien los temores que el gretagarbismo originó con respecto a la maternidad:

El «gretagarbismo» es en la actualidad más que una moda, más que una manía: es una locura epidémica, que de día en día causa mayores estragos. [...] Y así vemos en torno nuestro sucederse las transformaciones más asombrosas. Enflaquecen, hasta semejar angulosas calaveras, los rostros más perfectos. Se rasgan en heridas sangrantes los corazones - hoy tachados de «cursis»- de las bocas. Se agudizan mefistofélicamente las cejas más impecables. Se aclaran, se alisan y se revuelven las cabelleras más disciplinadas. Y sobre todo, ioh, sobre todo!, huyen de todos los ojos, y de todas las bocas, y de todos los gestos, y de todos los ademanes, la vida, la alegría, la espontaneidad. Las elegantes de aquí y de allá «melancolizan» a quien más, mejor. Como las de 1830, beberían gustosas vinagre si ello hiciera palidecer, no ya su cutis, sino su alma. Porque para lograr la expresión indispensable al nuevo rostro, hay que tornarse distante, indiferente, desdeñosa; enigmática, en una palabra ${ }^{68}$.

La alusión al vinagre traduce la preocupación mayor de la periodista: el cumplimiento de la maternidad. En la época del Romanticismo, el hecho de beber vinagre para lograr un rostro más pálido se insertaba dentro de una lógica de sumisión al patriarcado. En una época en la que se consideraba que los hombres dominados por sus instintos eran menos eficaces en su trabajo, las mujeres perseguían así un ideal de pureza y cultivaban una apariencia virginal y frígida. Este estado de enfermedad, poco compatible con la procreación, se veía como «una cualidad de la feminidad» ${ }^{69}$.

Tanto por sus personajes fílmicos que cuestionan la representación binaria de la feminidad y reflejan la voluntad de sublimar los estereotipos, como por su propio temperamento independiente e «indomable», Garbo invitó a ciertas espectadoras a materializar sus deseos, como lo evidencian ciertas entrevistas a actrices españolas. Conchita Montenegro confesó por ejemplo: «Cuando vi a Greta Garbo en El demonio y la carne, me entraron unas ganas locas de ser artista. Sentarme frente a un viejo escritorio, escribiendo números, cuando podía ver grandes actrices... ieso no me cuadraba, decididamente!» ${ }^{70}$. El título de un artículo dedicado a Rosita Díaz - «Rosita Díaz, la bella artista de la pantalla que hubiera querido ser novelista, tiene sus ideas acerca del divorcio y admira a Greta Garbo, la única»presenta a la actriz como un modelo de independencia a partir de la combinación de tres elementos: su ambición artística y creadora, su interés por el tema del divorcio y su admiración por Garbo. En la entrevista, la actriz se pronuncia a favor del sufragio femenino. Sin embargo, el periodista Martínez Gandía se opone rotundamente a la posibilidad de que Rosita Díaz pueda parecerse a Garbo:

[Rosita Díaz] - ¿A qué artista admiro más?... A Greta Garbo, la única. Es prodigiosa. Yo quisiera ser como ella. Pero yo no tengo cara de vampiresa, ¿verdad? No. Rosita no tiene cara de vampiresa, sino de todo lo contrario. Rosita ha de ser en el cine una muchacha traviesa y sentimental, como Nancy Carroll y como Marion Davies ${ }^{71}$. 
El estudio de la construcción de la imagen de Greta Garbo en la prensa cinematográfica de los años veinte y treinta indica que esta estrella fue primero recibida de forma muy positiva, debido a lo inaudito del modelo femenino que encarnaba en un momento en el que los públicos, y aún más el público español, estaban cansados de contemplar vampiresas estereotipadas que resucitaban la figura de Carmen. En los años treinta, el discurso laudatorio subsistió, pero convivió con una fuerte oposición que tradujo un miedo frente al poder demiúrgico de esta estrella que «usurpaba» la prerrogativa masculina de la creación en una etapa bisagra de la historia de las mujeres españolas. A raíz de este trabajo, se comprueba cómo el análisis de la recepción de una estrella extranjera puede revelar la existencia de debates poco sospechados en la cultura cinematográfica española, en particular la polémica en torno al autor del film y la voluntad de extirpar los modelos femeninos inaceptables que sobrepasaban con creces los avances logrados en cuanto a la condición femenina. Greta Garbo actuó, pues, como catalizador de estos límites y de las tensiones que provocaba el espectro de la mujer moderna. Si bien es cierto que algunos mecanismos descritos como el entusiasmo del público femenino y el recelo de los hombres frente al modelo problemático encarnado por Garbo no son exclusivos del caso español, es indudable que dichos fenómenos alcanzaron especial relevancia en una España marcada por una redefinición de la condición de la mujer en la sociedad, enriqueciendo los debates al respecto y revelándolos en su complejidad.

\section{BIBLIOGRAFÍA}

Aguilar, Santiago, «La vida amorosa de Greta en la pantalla. John Gilbert: el amante de ficción que quiere ser amante de verdad» (Cinegramas, n. ${ }^{\circ}$ 13, 9 de diciembre de 1934). Albertini, Pierre, «Une tradition étrangère à la classe ouvrière». Disponible en: <http:// lmsi.net/Une-tradition-etrangere-a-la> (20/02/2017).

Andreu Miralles, Xavier, «La mirada de Carmen. El mite oriental d'Espanya i la identitat nacional» (Afers: fulls de recerca i pensament, vol.19, n. ${ }^{\circ} 48,2004$ ), pp. 347-367. [Anónimo], [sin título], Popular Film (n. ${ }^{0}$ 208, 24 de julio de 1930).

ArconadA, César, Vida de Greta Garbo (Madrid, Miguel Castellote, 1974 [1929]). 
Aresti Esteban, Nerea, Médicos, donjuanes y mujeres modernas: los ideales de feminidad y masculinidad en el primer tercio del siglo XX (Bilbao, Universidad del País Vasco, 2001).

-, «La mujer moderna, el tercer sexo y la bohemia en los años veinte» (Dossiers féministes, Universitat Jaume I, Seminari d'Investigació Feminista, n. ${ }^{0}$ 10, 2007), pp. 173185. Disponible en: <http://www.raco.cat/index.php/DossiersFeministes/article/ view/102546> (01/03/2017).

-, Masculinidades en tela de juicio: hombre y género en el primer tercio del siglo XX (Madrid, Cátedra, 2010).

Bell-Metereau, Rebecca, Hollywood Androgyny (New York, Columbia University Press, 1985).

BLASCo IbáÑ̃z, Vicente, Entre naranjos (Madrid, Cátedra, 2009).

BRooks, Louise, Lulu in Hollywood (New York, Knopf, 1982).

BuñuEL, Luis, «Variaciones sobre el bigote de Menjou» (La Gaceta Literaria, n. ${ }^{\circ} 35$, junio de 1928).

Burch, Noël, «Double Speak. De l'ambiguïté tendancielle du cinema hollywoodien» (Réseaux, CNET/Hermès Science Publication, vol. 18, n. ${ }^{\circ}$ 99, 2000), pp. 99-130.

-, «Des effets pervers de la notion d'auteur», en Noël Burch y Geneviève Sellier, Le cinéma au prisme des rapports de sexe (París, Vrin, 2009), pp. 91-105.

CAsinos Guillén, Arturo, «Desorientación en las masas» (Popular Film, n. ${ }^{\circ} 343,9$ de marzo de 1933).

Champín Antoli, Luis, «El cine revoluciona al mundo, I» (Popular Film, n. ${ }^{\circ}$ 116, 18 de octubre de 1928).

Chaudron, Martine, «Pourquoi la catégorie "film d'auteur" s'impose-t-elle en France précisément ?» (Sociologie de l'Art, París, L'Harmattan, vol. 11 \& 12, n. ${ }^{\circ}$ 1, 2008, pp. 101-138).

«CIL», «Gretagarbismo» (El Sol, 9 de abril de 1933).

CONGEt, José María, Viento de cine: el cine en la poesía de expresión castellana. 19oo1999 [selección, introducción y notas] (Madrid, Hiperión, 2002).

Coquillat, Michelle, La poétique du mâle (París, Gallimard, 1982).

Dномме́е, Isabelle, Les cinq «empoisonneuses»: G. Garbo, J. Crawford, M. Dietrich, M. West, K. Hepburn et les États-Unis des années trente. Analyse du phénomène social de la star (Tesis doctoral, París, Université Sorbonne Nouvelle Paris III, 2000).

DIJKSTRA, Bram, Ídolos de perversidad: la imagen de la mujer en la cultura de fin de siglo (Madrid, Debate/Barcelona, Círculo de lectores, 1994).

Dottin-Orsini, Mireille, Cette femme qu’ils disent fatale. Textes et images de la misogynie fin de siècle (París, Bernard Grasset, 1993), pp. 274-305.

Eley, Geoff, "Culture, Nation and Gender», en Ida Blom, Karen Hagemann, Catherine Hall (dirs.), Gendered Nations. Nationalisms and Gender Order in the Long Nineteenth-Century (Oxford / New-York, Berg, 200o), pp. 27-40.

Fernandez, Dominique, Le rapt de Ganymède (París, Grasset, 1989).

FERri, Apolo M. , «Greta Garbo» (El Cine, n. ${ }^{\circ}$ 801, 18 de agosto de 1927).

Fischer, Lucy, Designing Women: Cinema, Art Deco and the Female Form (New York, Columbia University Press, 2003).

García Carrión, Marta, Por un cine patrio. Cultura cinematográfica y nacionalismo español (1926-1936) (Valencia, Publicacions de la Universitat de València, 2013).

Geraghty, Christine, «Re-examining Stardom: Questions of Texts, Bodies, and Performances», en Christine Gledhill y Linda Williams (dirs.), Reinventing Film Studies (London, Arnold, 2000), pp. 183-201. 
Guzmán Merino, Antonio, «¿̇A qué ha venido el cine?, I» (Popular Film, n. ${ }^{\circ}$ 358, 22 de junio de 1933).

-, «Hace falta un heresiarca» (Popular Film, n. ${ }^{\circ} 419,23$ de agosto de 1934).

Hansen, Miriam, «Pleasure, Ambivalence, Identification: Valentino and Female Spectatorship», en Christine Gledhill (dir.), Stardom: Industry of Desire (London, Routledge, 1991), pp. 259-282.

HERAs, Antonio, «Informaciones del cine: la figura de Greta Garbo» (Mundo Gráfico, n. ${ }^{\circ}$ 960, 26 de marzo de 1930).

Hernández Catá, Alfonso, «La voz de Greta Garbo» ( $l a$ Voz, 3 de diciembre de 1930).

Hernández Eguíluz, Aitor, Testimonios en huecograbado. El cine de la $2^{a}$ República y su prensa especializada (1930-1939) (Valencia, Ediciones de la Filmoteca, 2009).

«JEANNE», «La estela de Greta Garbo» (Cinema: revista española, noviembre de 1931).

LABRI, Fernando, «Estrellas rivales» (Cine-Art, n. ${ }^{\circ} 33,30$ de mayo de 1934).

LeConte, Loredana, «Latin Charm. Inventing Rudolph Valentino», en Giannino Malossi (dir.), Latin Lover: the Passionate South (Milan, Charta, 1996), pp. 81-93.

LEGIDO, Victoria, «De la mujer objeto a la mujer sujeto. Representaciones femeninas en la imagen fotográfica», en Ángela Figueruelo Burrieza et al. (dirs.), Las mujeres en la Constitución europea: estudios multidisciplinares de género (Salamanca, Ediciones Universidad Salamanca, 2005).

MAR, Alberto, «Carta abierta a Rafael Gil... sobre la "generación” de Popular Film...» (Popular Film, n. ${ }^{0}$ 517, 16 de julio de 1936).

Marañón, Gregorio, Don Juan (Madrid, Espasa-Calpe, 1976).

MARKHAM, Doris, «An Idyl or a Tragedy - Which?» (Motion Picture Magazine, diciembre de 1926).

Martínez Gandía, Rafael «Nita Naldi, vampiresa de ayer» (Mundo Gráfico, n. ${ }^{\circ}$ 992, 5 de noviembre de 1930).

-, «Rosita Díaz, la bella artista de la pantalla que hubiera querido ser novelista, tiene sus ideas acerca del divorcio y admira a Greta Garbo, la única» (Crónica, 22 de noviembre de 1931).

Morx, Terenci, La Gran Historia del Cine (Madrid, ABC, 1996).

Morin, Edgar, Las stars. Servidumbres y mitos (Barcelona, Dopesa, 1972).

De Ossorio, Fernando, «Greta Garbo y Don Juan» (Popular Film, n. ${ }^{0}$ 268, 1 de octubre de 1931).

PARIs, Barry, Garbo (Minneapolis, University of Minnesota Press, 2005 [1995]).

Pego, Aurelio, «Catalina, eje» (Popular Film, n. ${ }^{\circ} 399,5$ de abril de1934).

Sánchez Diana, Pedro, «Realizadores e intérpretes, I» (Popular Film, n. ${ }^{\circ}$ 300, 12 de mayo de 1932).

-, «Primer Arte» (Popular Film, n. ${ }^{\circ}$ 303, 2 de junio de 1932).

-, «La usurpadora y su realizador» (Popular Film, n. ${ }^{0} 369,7$ de septiembre de 1933).

-, «Gestas del cinema» (Popular Film, n. ${ }^{\circ}$ 412, 5 de julio de 1934).

SANTos, Mateo, «Muy femenina y muy española» (Popular Film, n. ${ }^{\circ}$ 364, 33 de agosto 1933).

Stacey, Jackie, Star Gazing: Hollywood Cinema and Female Spectatorship (London, New-York / Routledge, 1994).

TAPERT, Anette, The Power of Glamour (New York, Crown Publishers, 1998).

Torrella, José, «El alma del cine» (La Pantalla, n. ${ }^{\circ}$ 26, 18 de noviembre de 1928).

Urquiza, Conchita, «Conchita Montenegro, reflejo de la ardiente España» (El Cine, 19 de marzo de 1931). 
Ysern, Augusto, «Madrid-Cinema. Ecos y comentarios comprimidos» (Popular Film, n. ${ }^{\circ}$ 329, 1 de diciembre de 1932).

ZúÑIGA, Ángel, Una historia del cine (Barcelona, Destino, vol. 1 y 2, 1948).

-, La maravillosa mentira de Greta Garbo (Barcelona, G.P., h. 1953).

Recibido: 1 de marzo de 2017

Aceptado para revisión por pares: 3 de mayo de 2017

Aceptado definitivamente: 5 de octubre de 2017 
